\title{
Immunochemical and Physical Quantitation of Grass and Olive Pollen Allergens: Correlation With Asthma Admissions in Cáceres, Spain
}

\author{
Porcel Carreño S1', Gómez Nieves E1, Fernández-Caldas E²,3, Abel Fernández E², Cases B², Tudela Jl2, \\ Maghfour Martin $\mathrm{Y}^{1}$, Domínguez Domínguez $\mathrm{E}^{1}$, Alvarado Arenas $\mathrm{M}^{1}$, Jiménez Timón $\mathrm{S}^{1}$, Ahmida $\mathrm{T}^{1}$, \\ García Ponce JF¹, Jiménez Gallardo P¹, Alvarado Izquierdo MI', Hernández Arbeiza J¹
}

'Sección de Alergología, Complejo Hospitalario Universitario de Cáceres, Cáceres, Spain
${ }^{2}$ Inmunotek SL, Alcalá de Henares, Spain

${ }^{3}$ University of South Florida, College of Medicine, Tampa, USA

J Investig Allergol Clin Immunol 2020; Vol. 30(5): 334-339

doi: 10.18176/jiaci.0434

\begin{abstract}
Background: The association between pollen counts and allergen levels in the air is controversial.

Objectives: The aims of the study were to quantify total and major allergen levels of Phleum pratense and Olea europaea and to analyze their correlation with grass and olive pollen counts and the number of asthma attacks attended at Complejo Hospitalario Universitario, Cáceres, Spain.

Material and methods: A volumetric air sampler and a Burkard spore trap were used for pollen and aeroallergen collection during AprilJune 2011. Filters were extracted, and major allergens were quantified using enzyme-linked immunosorbent assay.

Results: May was the main grass pollination period, with a maximum peak of 1362 grains $/ \mathrm{m}^{3}$ (May 13). The main pollination period for olive was April 30-May 20, with a maximum peak of 851 grains $/ \mathrm{m}^{3}$ (May 11). A moderate correlation was observed between asthma exacerbations and grass pollen counts or Phleum total allergen levels; this became stronger when a 3-day offset was introduced. A significant association was observed between asthma exacerbations and total olive allergen or olive pollen grain levels when a 1-day offset was introduced. The maximum correlation (moderate-high) was observed 4 days and 6 days away from the maximum olive pollen peak and the maximum Ole e 1 peak level, respectively.

Conclusions: This study reveals a significant correlation between grass and olive pollination and an increase in the number of visits to the emergency room for asthma attacks. The aerobiological pattern of allergen levels in the air is similar to that of pollen counts during the grass and olive pollination periods.
\end{abstract}

Key words: Grass. Olive. Pollen. Allergens. Levels. Phl p 1. Phl p 5. Ole e 1.

\section{Resumen}

Antecedentes: La relación entre los niveles de pólenes en el aire y los niveles de alérgenos es controvertida.

Objetivos: El objetivo de este estudio fue cuantificar los niveles de alérgenos principales y totales de Phleum pratense y Olea europaea, y analizar su relación con los niveles de pólenes y el número de crisis asmáticas atendidas en el Complejo Hospitalario de Cáceres, España. Material y métodos: Se captaron pólenes y aeroalérgenos durante Abril-Junio de 2011, utilizando un colector de aire volumétrico y una trampa Burkard. Se extrajeron los alérgenos de los filtros y se cuantificaron mediante ELISA.

Resultados: Mayo fue el periodo de mayor polinización, (13 de Mayo, pico máximo de 1.362 granos de polen de gramíneas $/ \mathrm{m}^{3}$ ). El mayor periodo de polinización del olivo fue del 30 de Abril al 20 de Mayo, (11 de Mayo, pico máximo: 851 granos de polen de olivo/m³). Se observó una correlación moderada entre los niveles de polen o alérgenos totales y exacerbaciones de asma, que aumentó al introducir un desfase de 3 días (Phleum), y de 1 día (olivo). La máxima correlación se observó a los 4 y 6 días del pico máximo de polen y de Ole e 1, respectivamente.

Conclusiones: Este estudio muestra una correlación significativa entre la polinización de gramíneas y olivo y el aumento del número de visitas a urgencias debidas a crisis asmáticas. Los patrones aerobiológicos de los niveles de alérgenos en el aire son comparables a los recuentos de pólenes durante los periodos de polinización de gramíneas y olivo.

Palabras clave: Gramíneas. Olivo. Polen. Alérgenos. Niveles. Phl p 1. Phl p 5. Ole e 1. 


\section{Introduction}

The presence of pollen allergens in environmental air samples has been evaluated in various studies. These mainly examine the detection of pollen from grass [1-3], olive [4-6], Urticaceae [7,8], Betulaceae [9], ragweed [10,11], Plantago species [12], Platanus species [13], and Cupressaceae [14,15]. Pollen allergens have been detected in leaves or stems and pollen starch granules $[7,16,17]$, all of which contribute to the total allergen load. Allergens are released from pollen grains after exposure to water as submicron particles that leave the grain directly through the pollen pore (grasses), through a pollen tube (Betulaceae), or by exudation through the exine layer (Urticaceae) [18-20]. Some external factors, such as air pollution (diesel particles), can favor allergen release or act as vehicles for the allergens $[21,22]$.

The association between pollen counts and allergen levels in the air is controversial. While several authors report a low correlation coefficient for pollen and allergen levels, others have revealed the presence of the allergens in the environment before and after the pollination period [1-3,10,11].

Most allergens have molecular weights of less than $100 \mathrm{kDa}$, and can enter the airway easily [3,6]. Exposure to allergens can be measured by quantification of the pollen allergens in the air $[3,6]$. Some studies have shown the correlation between allergic symptoms in pollen-sensitized patients and pollen allergen levels to be better than that with the number of pollen grains $[2,4,14]$.

The aim of the present study was to quantify total allergen and major allergen levels in the air of Cáceres, Spain during the spring of 2011 and to analyze their correlation with (1) grass and olive pollen counts and (2) the number of asthma attacks evaluated at Complejo Hospitalario Universitario, Cáceres, Spain during this period.

\section{Material and Methods}

\section{Pollen Counts}

Pollen grain counts were measured using a Burkard spore trap (Burkard Manufacturing Co.) placed at a height of $15 \mathrm{~m}$ in Cáceres during the sampling period (April 11 to June 30, 2011). The airflow rate was $10 \mathrm{~L} / \mathrm{min}$. Pollen grains were caught on 24-mm wide transparent tape coated with a thin film of petroleum jelly mounted on a cylinder rotating at a speed of $2 \mathrm{~mm} / \mathrm{h}$. The adhesive tape (samples) was changed each Monday and divided into 7 parts, 1 for each day of the week. Samples were prepared according to the usual technique and examined under an optic microscope with a $40 \times$ objective lens. The pollen concentrations were expressed as pollen grains $/ \mathrm{m}^{3}$ of air.

\section{Air Sampling}

A volumetric air sampler (Air Sentinel, Quan-Tec-Air Inc.) was used for aeroallergen collection and run continuously during the study period. The sampler was in the same location as the Burkard spore trap. The air flow rate was $10 \mathrm{~m}^{3} / \mathrm{h}$. Airborne particles were collected by polytetrafluoroethylene filters (Quan-Tec-Air Inc.), which are $99.9 \%$ efficient at $0.3 \mu \mathrm{m}$.
The sampling time for each filter was 24 hours, that is, $240 \mathrm{~m}^{3}$ of air per sample. Filters were replaced at approximately the same time each day. After extraction, the filters were sealed in plastic bags and stored at $4^{\circ} \mathrm{C}$.

\section{Filter Extraction and Allergen Quantification}

A total of 111 polytetrafluoroethylene filter membranes were collected and individually extracted in tubes containing $0.5 \mathrm{~mL}$ of $0.01 \mathrm{M}$ phosphate-buffered saline. Each tube was stirred until the filter was completely wet and incubated overnight in a Rotary mixer (Labinco B.V.) at $4^{\circ}$ C. Samples were then centrifuged, and the supernatant was collected and processed immediately to avoid loss of allergenic activity. Total allergenic activity and allergen content were measured in eluted samples using a validated enzyme-linked immunosorbent assay. Total Phleum and olive pollen allergenic activity were measured using in-house reference preparations and enzyme-linked immunosorbent assay. Phl p 1, Phl p 5, and Ole e 1 (Bial Aristegui) were measured following the manufacturer's instructions. Positive and negative controls were also included. The percentage inhibition was calculated using the corresponding inhibition curve determined from the pollen analyzed. Allergen concentrations were extrapolated using the standard curve and based on the inhibition capacity; the final results were expressed in micrograms of allergen per milliliter.

\section{Emergency Department Visit Data}

Complejo Hospitalario Universitario de Cáceres covers an area of approximately $10500 \mathrm{~m}^{2}$ and serves 196000 inhabitants in southwestern Spain through 2 hospitals in the center of the city. A record was made of all the visits to the emergency department for asthma from April to June 2011. The computer record of the admissions area of the emergency department was reviewed. The emergency department files and the medical reports of the cases were subsequently reviewed to select those compatible with an asthma exacerbation. The study was approved by the hospital ethics committee.

\section{Statistical Analysis}

Correlations between pollen grain concentrations, aeroallergen levels, and asthma exacerbations were analyzed using GraphPad Prism for Windows. The Pearson rank correlation and $P$ values were obtained for each analysis.

\section{Results}

\section{Pollen Counts}

The grass pollen levels quantified for the whole year of 2011 (12 561 grains $/ \mathrm{m}^{3}$ ) represented $29 \%$ of total pollen grain levels. May was the main grass pollination period (10 579 grains $/ \mathrm{m}^{3}$ ), with a peak of 1362 grains $/ \mathrm{m}^{3}$ on May 13 .

Levels of olive pollen grains in 2011 (6998 grains $\left./ \mathrm{m}^{3}\right)$ accounted for $16.18 \%$ of the total pollen grain levels. The main olive pollination period was from April 30 to May 20 $\left(5892\right.$ grains $\left./ \mathrm{m}^{3}\right)$, with a peak of 851 grains $/ \mathrm{m}^{3}$ on May 11 . 
A

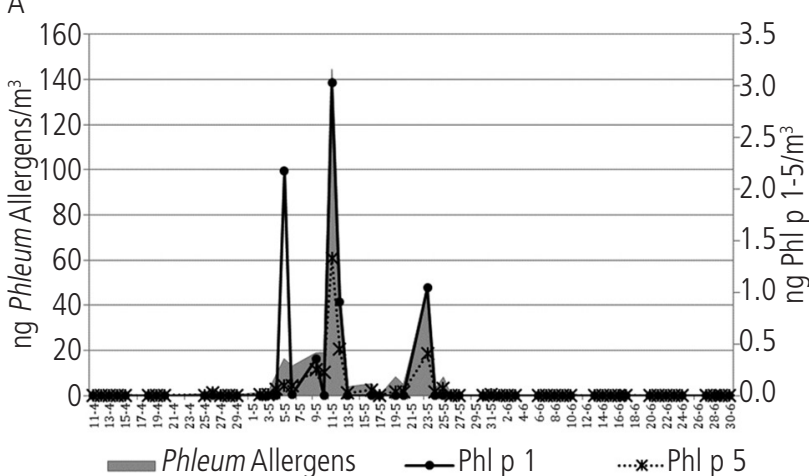

B

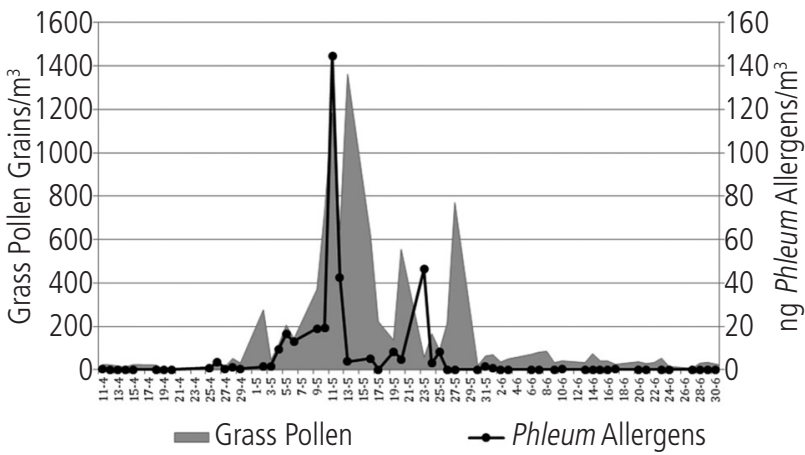

Figure 1. A, Correlation between total Phleum pratense allergen levels (ng Phleum allergens $/ \mathrm{m}^{3}$ ) and $\mathrm{Phl} \mathrm{p} 1$ and Phl p 5 major allergen levels (ng Phl p 1-5/m3): P pratense total allergen levels vs Phl $p 1, r=0.78$, $P<.0001$; total $P$ pratense allergen levels vs $P h l p 5, r=0.85, P<.0001$. $B$, Correlation between grass pollen grain counts (grass pollen grains $/ \mathrm{m}^{3}$ ) and total $P$ pratense allergen levels (ng Phleum allergens $/ \mathrm{m}^{3}$ ): grass pollen grains vs $P$ pratense allergens $r=0.57$.

\section{Immunochemical Quantification of Aeroallergens}

The highest levels of total grass allergen activity, as measured with the $P$ pratense immunoassay, were detected between May 4 and May 25. The maximum peak value was recorded on May 11 (P pratense total allergen level, $145 \mathrm{ng} / \mathrm{m}^{3}$; Phl p 1 level, 3 ng/m³; Phl p 5 level, $1 \mathrm{ng} / \mathrm{m}^{3}$ ).

The highest levels of total olive allergen were detected between May 5 and 25. The maximum peaks for olive allergens were recorded on May 6 (total olive allergen level, $153 \mathrm{ng} / \mathrm{m}^{3}$; Ole e 1 level, $11 \mathrm{ng} / \mathrm{m}^{3}$ ) and May 9 (total olive allergen level, $104 \mathrm{ng} / \mathrm{m}^{3}$; Ole e 1 level, $19 \mathrm{ng} / \mathrm{m}^{3}$ ).

\section{Asthma Exacerbations}

From April to June, 111 visits to the emergency department due to asthma exacerbations were registered (18 in April, 80 in May, and 13 in June). Twenty-two patients (ages from 5 to 88 , mean age 37 ) were admitted to hospital, 15 during May.

\section{Correlation Between Pollen Counts, Aeroallergen Concentrations, and Asthma Exacerbations}

A positive correlation was observed between total $P$ pratense allergen levels and the Phl p 1 and Phl p 5 major

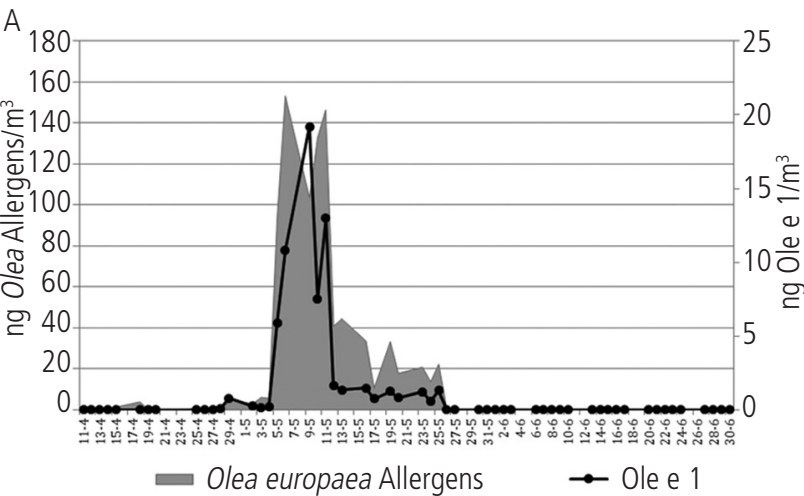

B

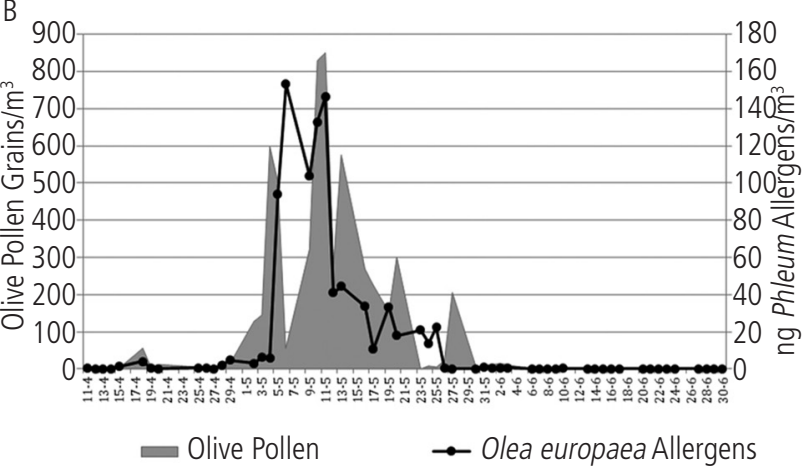

Figure 2. A, Correlation between total Olea europaea allergen levels (ng Olea allergens $/ \mathrm{m}^{3}$ ) and Ole e 1 major allergens levels (ng Ole e $1 / \mathrm{m}^{3}$ ): $r=0.88, P<.0001$

$B$, Correlation between olive pollen grain counts (olive pollen grains $/ \mathrm{m}^{3}$ ) and total Olea allergen levels (ng Olea allergens $/ \mathrm{m}^{3}$ ): $r=0.71, P<.0001$.

allergen levels, as follows: $P$ pratense vs $\mathrm{Phl} \mathrm{p} 1, \mathrm{r}=0.78$, $P<.0001 ;$ P pratense vs Phl p 5, $\mathrm{r}=0.85, P<.0001$ (Figure 1A). A moderate positive correlation between grass pollen grain counts and allergen levels was observed, as follows: grass pollen grains vs $P$ pratense allergens, $\mathrm{r}=0.57, P<.0001$ (Figure 1B); grass pollen grains vs $\mathrm{Phl} \mathrm{p} \mathrm{1,} \mathrm{r=0.45,} P<.0001$; grass pollen vs $\mathrm{Phl} \mathrm{p} 5, \mathrm{r}=0.58, P<.0001$ (data not shown). The highest pollen levels and the lowest allergen levels were recorded on May 13, probably owing to the presence of grass pollens from species such as Cynodon dactylon, which do not fully cross-react with $P$ pratense.

Positive correlations were observed between total $O$ europaea allergen levels and Ole e 1 allergen content $(\mathrm{r}=0.88, P<.0001)$ (Figure $2 \mathrm{~A})$, between olive pollen grains and olive allergens $(\mathrm{r}=0.71, P<.0001)$ (Figure $2 \mathrm{~B})$, and between olive pollen grains and Ole e $1(\mathrm{r}=0.57, P<.0001)$.

The Table shows the results for the correlation between visits to the emergency room for asthma exacerbations and the levels of the different allergens. Correlations were observed between grass pollen counts or Phleum total allergen levels and asthma exacerbations. When a 3-day offset was introduced, the correlation increased to a moderate range.

A significant association was also observed between asthma exacerbations and levels of olive allergens or olive pollen 
grains when a 1-day offset was introduced. The maximum correlation (moderate-high) was observed 4 days away from the maximum olive pollen peak and up to 6 days after the maximum Ole e 1 peak.

\section{Discussion}

Grass and olive tree are 2 of the main sources of pollen in Spain. The Cáceres aerobiological station has been working since 2008, and pollen measurements made during 2008-2016 (unpublished data) revealed that grass pollen is one of the most prevalent pollens detected in the air (mean annual values, 8237 grains $/ \mathrm{m}^{3}$ ), followed by Quercus species pollen (8462 grains/ $\mathrm{m}^{3}$ ). These values account for $25 \%$ of the total pollen grain count $/ \mathrm{m}^{3} /$ year. Grass pollination is mainly in May, between weeks 17 and 22, with peaks of $>1000$ grains $/ \mathrm{m}^{3}$. Olive tree constitutes the third main pollen taxon in Cáceres, depending on the year, with a main pollination period between weeks 18 and 21 and average levels of 4124 grains $/ \mathrm{m}^{3} /$ year.

Most of the patients from this region are sensitized to pollens and show signs and symptoms of rhinoconjunctivitis and asthma, with a higher frequency and intensity during May, when the grass and olive pollens are predominant. The results obtained in this study reveal the importance of 2011 in terms of grass and olive pollen counts. The pollen levels obtained during this period were above average, with a grass pollen peak of 1362 grains $/ \mathrm{m}^{3}$ on May 13, that is, the maximum level registered in the Cáceres aerobiological station.

During the period studied, the number of visits to the emergency room for asthma attacks (80 visits) increased in May, consistent with the maximum pollination period for grasses and olive trees. The highest number of visits was registered during May 12-19 (25 visits). The results revealed a correlation between grass pollen counts and the number of visits due to asthma exacerbations. This correlation was significantly higher with a 3-day deviation from exposure to pollens or allergens. A positive correlation was also observed between olive pollen counts and the number of visits. This correlation was significantly higher with a 1-day deviation from exposure to pollens, or a 6-day deviation from exposure to olive allergens. These results are in agreement with those of previous studies analyzing the association between asthma exacerbations and grass or Quercus species pollination in the United States [23], grass pollination in Australia [24], and grass and Urticaceae pollination in Spain [25-27]. The delayed allergic response (asthma exacerbations and daily records of symptoms) after exposure to pollen or allergen has also been observed elsewhere [4,25,27].

The effects of air pollution (not analyzed in our study) in patients sensitized to pollen could contribute to poorer control of seasonal allergic rhinitis [28] and asthma, with an increased risk of exacerbations [29,30]. Nevertheless, other studies suggest that pollination is an independent risk factor for asthma exacerbations $[1,23,27]$.

Feo et al $[2,4]$ also studied the relationship between pollen counts, allergen levels, and rhinoconjunctivitis and/or allergic asthma in patients monosensitized to grass or olive pollen in Ciudad Real, Spain. The authors established a clinical response threshold of $18 \mathrm{ng}$ of total grass allergen $/ \mathrm{m}^{3}$ and $22.7 \mathrm{ng}$ of olive allergen $/ \mathrm{m}^{3}\left(0.9 \mathrm{ng}\right.$ Ole e $\left.1 / \mathrm{m}^{3}\right)$. In the present study, these grass allergen levels were registered on 5 days during May, although the threshold levels of grass pollen grains proposed by the authors ( 35 grains $/ \mathrm{m}^{3}$ ) were exceeded on most of the days, and on May 11, a peak of $145 \mathrm{ng}$ grass allergen $/ \mathrm{m}^{3}$ was observed.

Some authors have suggested that pollen potency, or the quantity of allergens/grain of pollen, depends on the area studied $[5,31]$. The grass pollen allergenicity obtained between April 11 and May 30 in the present study was $40 \mathrm{pg}$ of P pratense allergen/pollen grain, $0.87 \mathrm{pg}$ of $\mathrm{Phl} \mathrm{p} \mathrm{1/pollen} \mathrm{grain,}$ and $0.32 \mathrm{pg}$ of $\mathrm{Phl}$ p 5/pollen grain. These values are lower than the allergenic potency obtained by the HIALINE Working Group in a multicenter study performed in 10 European countries (2-2.5 pg of Phl p 5/pollen grain) [31].

The olive pollen potency obtained in Cáceres during the period analyzed is higher than that obtained by other

Table. Pearson Correlation Test for Emergency Department Visits According to Asthma, Pollen Counts, and Aeroallergen Levels

\begin{tabular}{|c|c|c|c|c|c|}
\hline & $\begin{array}{c}\text { Asthma } \\
\text { Exacerbations (AE) }\end{array}$ & AE 1-Day Lag & AE 3-Day Lag & AE 4-Day Lag & AE 6-Day Lag \\
\hline Grass pollen & $\begin{array}{c}\mathrm{r}=0.313 \\
(P=.0055)\end{array}$ & $\begin{array}{c}\mathrm{r}=0.488 \\
(P=1.05 \times 10-6)\end{array}$ & $\begin{array}{c}\mathrm{r}=0.575 \\
(P=4.58 \times 10-9)\end{array}$ & & \\
\hline $\mathrm{Phl} \mathrm{p} g, \mathrm{ng} / \mathrm{m}^{3}$ & $\begin{array}{c}\mathrm{r}=0.259 \\
(P=.0224)\end{array}$ & $\begin{array}{c}\mathrm{r}=0.298 \\
(P=.0042)\end{array}$ & $\begin{array}{c}\mathrm{r}=0.644 \\
(P=1.30 \times 10-11)\end{array}$ & & \\
\hline 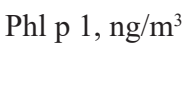 & $\begin{array}{c}\mathrm{r}=0.120 \\
(P=.2974)\end{array}$ & $\begin{array}{c}\mathrm{r}=0.232 \\
(P=.0275)\end{array}$ & $\begin{array}{c}\mathrm{r}=0.525 \\
(P=1.51 \times 10-7)\end{array}$ & & \\
\hline 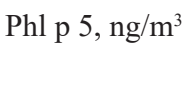 & $\begin{array}{c}\mathrm{r}=0.123 \\
(P=.2856)\end{array}$ & $\begin{array}{c}\mathrm{r}=0.290 \\
(P=.0054)\end{array}$ & $\begin{array}{c}\mathrm{r}=0.670 \\
(P=8.60 \times 10-13)\end{array}$ & & \\
\hline Olive pollen & $\begin{array}{c}\mathrm{r}=0.180 \\
(P=.1823)\end{array}$ & $\begin{array}{c}\mathrm{r}=0.656 \\
(P=.00091)\end{array}$ & & $\begin{array}{c}\mathrm{r}=0.7163 \\
(P=6.20 \times 10-15)\end{array}$ & \\
\hline Ole e, $n g / \mathrm{m}^{3}$ & $\begin{array}{c}\mathrm{r}=0.124 \\
(P=.3609)\end{array}$ & & & & $\begin{array}{c}\mathrm{r}=0.6078 \\
(P=6.88 \times 10-10)\end{array}$ \\
\hline Ole e $1, \mathrm{ng} / \mathrm{m}^{3}$ & $\begin{array}{c}\mathrm{r}=0.074 \\
(P=.5849)\end{array}$ & & $\begin{array}{c}\mathrm{r}=0.5073 \\
(P=4.54 \times 10-7)\end{array}$ & & $\begin{array}{c}\mathrm{r}=0.7201 \\
(P=7.97 \times 10-15)\end{array}$ \\
\hline
\end{tabular}


authors [5]. On 11 days, between May 5 and 25, the threshold levels of total olive allergen (peak of $153 \mathrm{ng} / \mathrm{m}^{3}$ ) and Ole e 1 (peak of $19 \mathrm{ng} / \mathrm{m}^{3}$ ) were exceeded, and the allergen values obtained per pollen grain were $159 \mathrm{pg}$ of olive allergen/pollen grain and 12 pg Ole e 1/pollen grain.

A positive correlation between pollen counts obtained by microscopy and allergen levels in air quantified by immunochemical methods has been found in grasses. However, on May 13, 16, 20, and 27, pollen counts were high and allergen levels were low. In contrast, on May 23, pollen counts were low and allergen levels were high. A better positive correlation was found between olive pollen counts and the allergen levels, especially in the total allergen level measurement $(\mathrm{r}=0.71)$. Exceptions were also found on May 2 (high pollen counts and low allergen levels) and May 6 (low pollen counts and high allergen levels). This low correlation has been observed in several studies, where allergen levels are maintained or even increase after the pollination period $[1,2,6]$.

Correlations for pollen from trees seem to be better than those for pollen from grasses, with allergen levels limited to the pollination period, as occurs with olive tree [4,5], Platanus [13], Betula [9], and Cryptomeria japonica [14], compared with grass [1,2], Ambrosia [10,11], Parietaria [7], and Plantago [12]. These differences may be due to the presence of numerous grass species in this area and to a potential lack of cross-reactivity between them.

This study focuses on spring, although allergen measurements were made until November. There were no relevant levels of grass or olive allergens outside the pollination period. The presence of grass and olive allergens in the environment of Cáceres seems to be linked to the presence of pollen. Allergen and pollen measurements could be used as indicators of asthma exacerbations.

In conclusion, this study monitors pollen grain and allergen levels during spring in Caceres, Spain. It reveals a significant correlation between grass and olive pollination and an increased number of visits to the emergency department owing to asthma attacks in Cáceres. The aerobiological pattern of allergen levels in the air is comparable to that of the pollen counts during the grass and olive pollination periods. Although total levels and maximum peaks of olive pollen in Cáceres are lower than the equivalent grass pollen levels, the results obtained reveal greater allergenic potency in olive pollen, a better correlation between pollen counts and allergen levels, and a more robust association with exacerbation of the disease in asthmatic patients.

\section{Funding}

The authors declare that no funding was received for the present study.

\section{Conflicts of Interest}

The authors declare that they have no conflicts of interest.

\section{References}

1. Cabrera M, Martinez Cócera C, Fernández-Caldas E, Carnés J, Boluda L, Tejada J, et al. Trisetum paniceum (Wild oats) pollen counts and aeroallergens in the ambient air of Madrid, Spain. Int Arch Allergy Immunol. 2002;128:123-9.

2. Feo Brito F, Mur P, Carnés J, Fernández-Caldas E, Lara P, Alonso AM, et al. Grass pollen, aeroallergens, and clinical symptoms in Ciudad Real, Spain. J Invest Allergol Clin Immunol. 2010;20:295-302.

3. De Linares C, Díaz de la Guardia C, Nieto D, Alba F. Airborne study of grass allergen (Lol p 1) in different-sized particles. Int Arch Allergy Immunol. 2010;152:49-57.

4. Feo F, Mur P, Carnés J, Martín R, Fernández-Caldas E, Lara $P$, et al. Olea europaea pollen counts and aeroallergen levels predict clinical symptoms in patients allergic to olive pollen. Ann Allergy Asthma Immunol. 2011;106:146-52.

5. Galán C, Antunes C, Brandao R, Torres C, García-Mozo

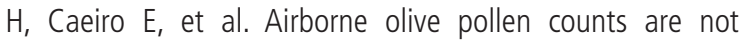
representative of exposure to major olive allergen Ole e 1 . Allergy. 2013;68:809-12.

6. De Linares C, Nieto D, Alba F, Galán C, Trigo M. Detection of airborne allergen Ole e 1 in relation to Olea europaea pollen in Spain. Clin Exp Allergy. 2007;37:125-32.

7. Jato V, Rodríguez J, González Z, Elvira B, Moreno S, Vega A, et al. Detection or airborne Par j 1 and Par j 2 allergens in relation to Urticaceae pollen counts in different bioclimatic areas. Ann Allergy Asthma Immunol. 2010;105:50-6.

8. Moreno S, Elvira B, Moreno J, García A, Vergara N, Asturias J, et al. Correlation between Olea europaea and Parietaria judaica pollen counts and quantification of their major allergens Ole e 1 and Par j 1-Par j 2. Ann Allergy Asthma Immunol. 2006;96:858-64.

9. Buters J, Thibaudon M, Smith M, Kennedy R, Rantio A, Albertini $R$, et al. The Hialine working Group. Release of Bet $v 1$ from birch pollen from 5 European countries. Results from the HIALINE study. Atmospheric Environment. 2012;55:496-505.

10. Agarwal MK, Swanson MC, Reed CE, Yunginger JW. Immunochemical quantitation of airborne short ragweed, Alternaria, antigen E, and Alt-I allergens: a two-year prospective study. J Allergy Clin Immunol. 1983;72:40-5.

11. Barnes C, Schreiber K, Pacheco F, Landuyt J, Hu F, Portnoy J. Comparison of outdoor allergenic particles and allergen levels. Ann Allergy Asthma Immunol. 2000;84:47-54.

12. González Z, Fernández D, Camazón B, Valencia RM, Vega AM, Asturias J, et al. Molecular aerobiology - Plantago allergen Pla I 1 in the atmosphere. Ann Agric Environ Med. 2014;21:282-9.

13. Alcázar P, Galán C, Torres C, Domínguez E. Detection of airborne allergen (Pla a 1) in relation to Platanus pollen in Córdoba. Ann Agric Environ Med. 2015;22:96-101.

14. Takahashi Y, Aoyama M, Yoshitake M, Abe E, Ohta N, Sakaguchi M. Relation between airborne Cry j 1 and the onset time of the symptoms of Japanese cedar pollinosis patients. Allergol International. 2007:56:277-83.

15. Moreno F, Letrán A, del Cuvillo A, Lobatón P, García F, Espinazo $M$. Determination of allergenic load and pollen count of Cupressus arizonica pollen by flow cytometry using Cup a 1 polyclonal antibody. Cytometry Par B. 2014;86B:63-9.

16. Fernández-Caldas E, Bandele EO; Dunnette SL, Swanson MC, Reed CE. Rye grass cross-reacting allergens in leaves from seven different grass species. Grana. 1992;31:157-9.

17. Schappi G, Taylor P, Staff I, Rolland J, Suphioglu C. Immunologic significance of respirable atmospheric starch granules 
containing major birch allergen Bet v1. Allergy. 1999;54:47883.

18. Grote $M$, Vrtala $S$, Niederberger $V$, Wiermann $R$, Valenta $R$, Reichelt R. Release of allergen-bearing cytoplasm from hydrated pollen: A mechanism common to a variety of grass (Poaceae) species revealed by electron microscopy. J Allergy Clin Immunol. 2001;108:109-15.

19. Grote $M$, Valenta $R$, Reichelt R. Abortive pollen germination: A mechanism of allergen release in birch, alder, and hazel revealed by immunogold electron microscopy. J Allergy Clin Immunol. 2003;111:1017-23.

20. Vega AM, Fernández D, Valencia R, Suárez M. Detection and release of allergenic proteins in Parietaria judaica pollen grains. Protoplasma. 2006;228:115-20.

21. Motta AC, Marliere M, Peltre G, Sterenberg PA, Lacroix G. Traffic-related air pollutants induce the release of allergen containing cytoplasmic granules from grass pollen. Int Arch Allergy Immunol. 2006;139:294-8.

22. Knox RB, Suphioglu C, Taylor P, Desai R, Watson HC, Peng JL, et al. Major grass pollen allergen Lol p 1 binds to diesel exhaust particles: implications for asthma and air pollution. Clin Exp Allergy. 1997;27:246-51.

23. Darrow L, Hess J, Rogers C, Tolbert P, Klein M, Sarnat S. Ambient pollen concentrations and emergency department visits for asthma and wheeze. J Allergy Clin Immunol. 2012;130:630-8.

24. Hayden T, Muscatello D. Increased. Increased presentations to emergency departments for asthma associated with rye grass pollen season in inland NSW. NWS Public Health Bulletin. 2011;22:154-8.

25. Cirera L, García Marcos L, Giménez J, Moreno-Grau S, Tobías $A$, Pérez $V$, et al. Daily effects of air pollutants and pollen types on asthma and COPD hospital emergency visits in the industrial and Mediterranean Spanish city of Cartagena. Allergol Immunopathol. 2012;40:231-7.
26. Galán I, Prieto A, Rubio M, Herrero T, Cervigón P, Cantero JL, et al. Association between airborne pollen and epidemic asthma in Madrid, Spain: a case control study. Thorax. 2010;65:398-402.

27. Tobías A, Galán I, Banegas JR, Aránguez E. Short term effects of airborne pollen concentrations on asthma epidemic. Thorax. 2003;58:708-10.

28. Cabrera M, Garzón García B, Moreno Grau S, Subiza J. Relationship between air pollution, meteorological factors and grass pollen counts, with seasonal allergic rhinitis in Madrid (1996 and 2009). J Investig Allergol Clin Immunol. 2019;29(5). doi: 10.18176/jiaci.0368.

29. D'Amato M, Cecchi L, Annesi-Maesano I, D'Amato G. News on Climate Change, Air Pollution, and Allergic Triggers of Asthma. J Investig Allergol Clin Immunol. 2018;28(2):91-7.

30. Feo F, Mur P, Martínez C, Tobías A, Suárez L, Guerra F. Air pollution and seasonal asthma during the pollen season. $A$ cohort study in Puertollano and Ciudad Real (Spain). Allergy. 2007;62:1152-7.

31. Buters J, Prank M, Sifiev M, Pusch G, Albertini R, AnnesiMaesano I, et al. Variation of the Group 5 grass pollen allergen content of airborne pollen in relation to geographic location and time in season. J Allergy Clin Immunol. 2015;136:87-95. Manuscript received April 2, 2019; accepted for
publication July 5, 2019 .

\section{Enrique Fernandez-Caldas}

Calle Punto Mobi, 5

Alcala de Henares 28805 - Madrid

E-mail: efcaldas@inmunotek.com 